\title{
Students' Perception toward Social Media Assisted Language Learning (SMALL) for Arabic Learning
}

\author{
${ }^{1}$ Risna Rianti Sari ${ }^{*},{ }^{2}$ Albar Adetary Hasibuan \\ ${ }^{1}$ Islamic State University Maulana Malik Ibrahim Malang \\ *Email : risnainlearn@gmail.com \\ ${ }^{2}$ Brawijaya University Malang \\ albaradetaryhasibuan@ub.ac.id
}

Abstract

The aims of this research were to determine the perception of students of Arabic Language Department towards the use of social media in teaching Arabic language and determine social media often used by students to help in the process of teaching Arabic language. This study used social anthropology approach in qualitative research because this study focusses on student's perceptions towads mobile as their assistant for learning Arabic. The subject of study are 32 Arabic language education students at the State Islamic University Maulana Malik Ibrahim Malang. The results of the study show that social media can be used as a tool for language learning Arabic, can improve students' skills, and help them better interact with lecturers and classmates.

Keyword Arabic Language Teaching; Social Media; Students' Perception

$$
\begin{aligned}
& \text { هدف هذه البحث إلى تحديد موقف طلبة تعليم اللغة العربية نحو استخدام } \\
& \text { وسائل التواصل الاجتماعي في تعليم اللغة العربية ، وما هي وسائل التواصل } \\
& \text { الاجتماعي التي غالباً ما يستخدمونها الطلبة للمساعدة في عملية تعليم اللغة لهية } \\
& \text { العربية الخاصة بهم. استخدمت هذه الدراسة منهج الأنثروبولوجية }
\end{aligned}
$$

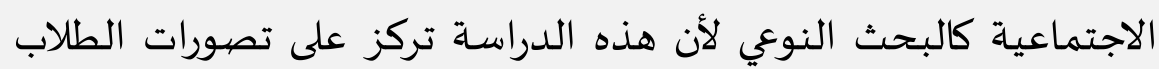

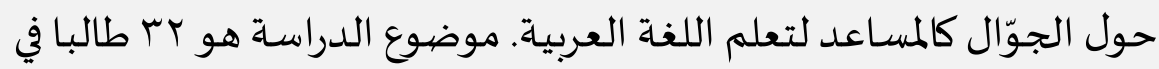

$$
\begin{aligned}
& \text { قسم تعليم اللغة العربية في جامعة مولانا مالك إبراهيم الإسلامية الحكومية } \\
& \text { مالانج. ظهرت نتائج الدراسـة أن الوسائل الاجتماعية يمكن استخداديه امها كأداة }
\end{aligned}
$$

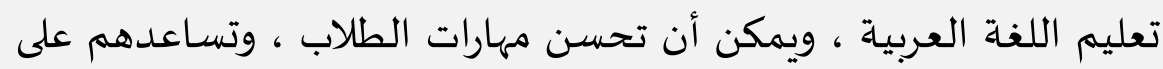

$$
\begin{aligned}
& \text { التفاعل بشكل أفضل مع المحاضرين وزملاء الدراسـة. }
\end{aligned}
$$
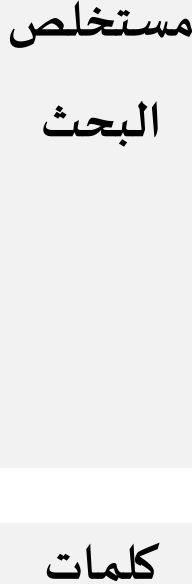

$$
\text { تعليم اللغة العربية؛ وسـائل التواصل الاجتماعي؛ موقف الطلبة }
$$




\section{INTRODUCTION}

Social media is something that must be owned by every individual today, because social media as a means of communication that can override social status and communication boundaries, such as distance to face each other, economic limitations to visit, and the rigidity of conversations during direct interaction. Its easy use caused social media close people's daily lives.

Social media is a new media which is growing rapidly at this time. In the beginning, communication was only done in one direction, then developed into a two-way interaction. One-way communication is also called old media, such as television, radio, newspapers and magazines. While new media offers to way interactions such as the internet (Watie, 2016). Social media such as social networking offers interaction that allows users to choose what information is consumed, while controlling the information that is shared.

The interaction freedom on social media results in a lot of information that spreads hoaxes. Andi Nugroho analyzed the spread of hoaxes on social media which led to the conclusion that naive users who only saw from his perspective did not care whether the information he got right or wrong was more prone to spread hoaxes (Nugroho, 2018). Naive social media users, more often see the content or the main title, then immediately spread without checking more details of the information. Especially if the information he gets from friends who are understanding, or sources that he believes are credible in loading information.

From the research above, one of the factors that causes good or bad social media is its users. Besides naive users, many wise users are using social media for development in various fields. For example, in the education field, because social media is close to school-age adolescents, users can infiltrate educational content that is easily accessible and beneficial to them. In other words, social media can help learners to improve the knowledge they want to master.

This also applies to learning foreign languages. Social media can help language teachers and learners in the learning process. Instagram, Facebook, WhatsApp, YouTube, Twitter, Line etc. are social media both application and message sending media that can be used as a means of learning foreign languages. Through Facebook, language learners can find groups that discuss the content of the target language they want to master. Also, YouTube, which provides foreign language learning content videos so that it can be used as great as possible by foreign language learners.

The emersion of social media in the field of foreign language learning raises different perception among students who are also digital natives. Some 
students argue that social media can help positively in enhancing second language learning, while others limit social media only as social interactions that are not necessarily involving learning. Activity of learning became more comfortable and more independent with mobile phone (Fauzi \& Anindiati, 2019:131).

Opinions about the use of social media have been widely studied among second language activists like Abuelqasm Sabah Elsaid Mohamed who research about students' attitude toward the use of social media for learning purpose in Al-Baha University. He found that the students' have positive attitude toward social media on their English language learning (Salih \& Elsaid, 2018). The other researcher was Omer Eren, who also researched about students' attitude toward using social networking in foreign language classes in this case was English language class in University of Gaziantep Turkey, and he concluded that Facebook was very useful as an educational tool (Eren, t.t.).

Research on the students' perception toward social media in learning as above has been studied in the field of English learning. It is inspiring the writer to bring these various views to the field of Arabic language learning by students of Arabic language education at the State Islamic University of Malang. Are the students also have positive perception toward social media in learning process or the contrary, they just used the social media for private interaction only.

\section{THEORITICAL FRAMEWORK}

\section{Social Media Assisted Language Learning}

The role of computers in helping to improve second language learning has been around since the 60's. There is the term CALL or computer assisted language learning, which is learning the second language with the help of computer applications. Lee (2000) states that computer use in second language learning can improve learner training through experiential learning, motivate learners to learn more, encourage closer interaction between instructors and learners, become authentic sources so that learners can access more than one source of information and can expand understanding globally (Afshari, Ghavifekr, Siraj, \& Jing, 2013a).

Besides CALL, it is also known as the CMC or computer mediated communication, which is a tool that can be used by instructors to explore learner abilities (Hasibuan, 2018). CMC is developing in line with the widespread internet network today so that it can be used by instructors and language learners to improve skills even listening, reading, writing and 
speaking. Email, group chat, electronic bulletin, edmodo, including kinds of CMC that can be used for language learning.

After the two terms above, the term MALL appears, it means mobile assisted language learning with including social media in it. Social media is undoubtedly used today, social media is one of the powerful sources of news and information. For example, Facebook, which is accessed every day by digital native, contains a lot of up-to-date information and news content. Other types of social media such as instagram, twitter, you tube and so on are not only able to share writing, but also contain audio, video, images, podcasts and other multimedia interactions.

From these social media advantages, SMALL or social media assisted language learning emerged, which was widely used to improve second language learning. SMALL is considered easier to use and more practical, because every information can be shared quickly. Mason (2006) claims that social media has a large role for high-quality education in accordance with the social setting in learning and fosters learner creative thinking (Baröz, 2016).

Many studies that utilize social media in the process of language learning. Suppose Voyce Li examines the use of social media for learning English and its relationship with six possible learning activities that are often carried out using social media. The conclusion of the study is that the most visible is the acquisition of high frequency material from social media both from you tube, wiki, Facebook or What Apps in learning English both formal and informal (English Language Centre, the Hong Kong Polytechnic University, Hong Kong, China \& Li, 2017).

Other study was Ismail et al., They examined social media use in Malaysian students studying at Jordanian universities. The results of the study show that Malaysian students have intermediate Arabic language levels in the practice of learning Arabic. The researcher also observed social media users including gender, level of learning, distance between residence and previous university and school (Ismail \& Yusof, 2012).

\section{SMALL in Arabic Learning}

The entry of Arabic into Indonesia is in line with the entry of Islam. According to Efendy (2004) Arabic is well known long before the Indonesian people knew other foreign languages such as Dutch, English and French (Murdiono, 2018). According to linguists, Arabic is the oldest language compared to languages derived from one mother-semitic language-such as Hebrew, Syrian and Habashiyah (Masqon, 2018). Now a day, Arabic is very familiar with Indonesians, because besides being a religion language, Arabic is also studied in schools as a world language. 
Today, learning Arabic in Indonesia is very developed. This is evidenced by the many recent studies that use media and technology in learning Arabic. One of them uses social media as a means of learning Arabic. Social media is often used in the dissemination of Arabic content such as Facebook, Instagram and also YouTube.

The first thing to do in the use of social media as a tool for learning Arabic is to prepare the media itself, starting with connecting to the internet network and downloading the desired social media applications, social media can be used individually or in groups. The next step is the instructor introduces a particular topic or theme that will be subject to study of Arabic learning. In their interactions, instructors can give assignments, or learners can ask for content that they have not understood, so that they can show the results of their learning on the social media. The last instructor must continue to act as an evaluator of the work of the learners they upload on social media.

The following pictures and figures are an example of using social media in learning Arabic.

Figure 1. Example of using social media Instagram in Arabic learning

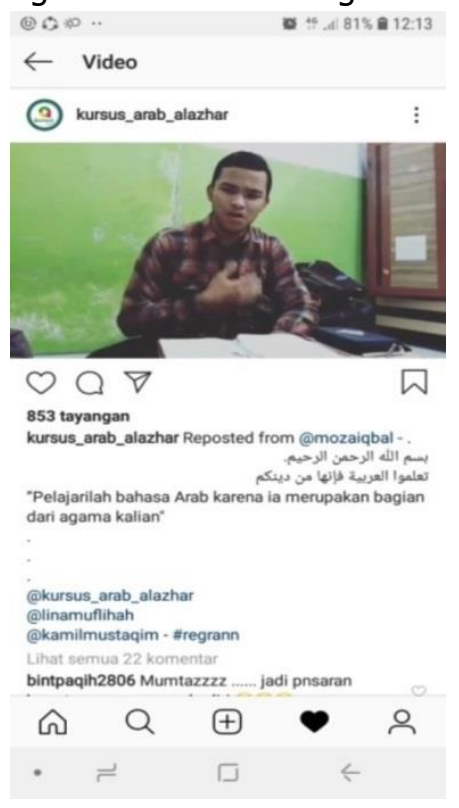

Figure 1 describes instructional video for Arabic learning. It used Instagram as social media for teaching and learning Arabic language. 
Figure 2. Example of using social media YouTube in Arabic learning

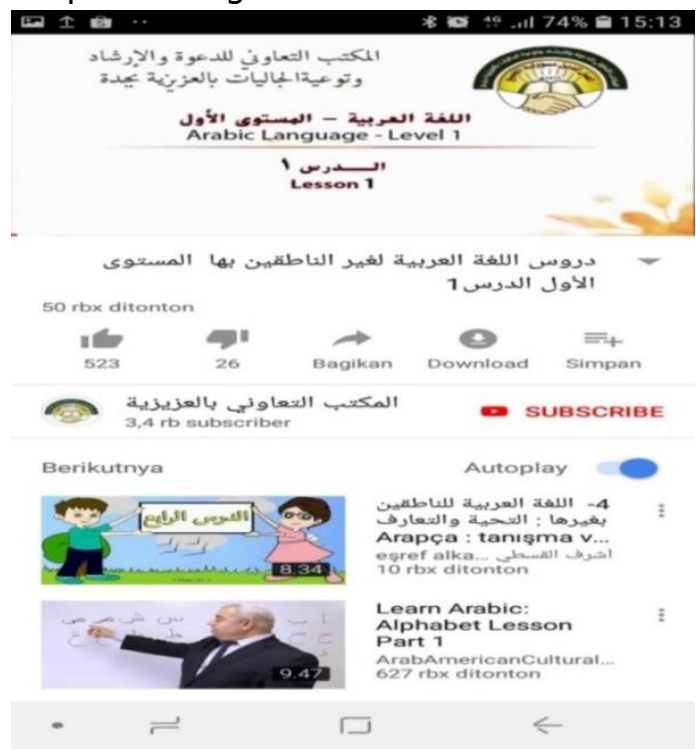

Figure 2 describes instructional video for Arabic learning. It used YouTube as social media for teaching and learning Arabic language.

Figure 3. Example of using social media Facebook in Arabic learning

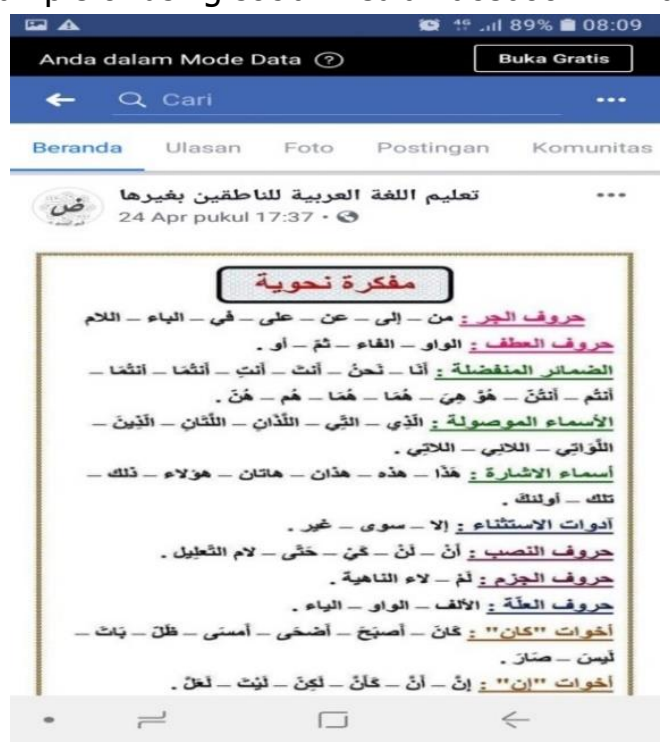

Figure 3 describes instructional video for Arabic learning. It used YouTube as social media for teaching and learning Arabic language.

\section{METHOD}

This study used social anthropology approach in qualitative research because this study focusses on student's perceptions towads mobile as their assistant for learning Arabic. 


\section{Sample, Instrument, and Analysis}

The subject of study are 32 Arabic language education students at the State Islamic University Maulana Malik Ibrahim Malang. Consist of 3 levels of language skill, expert, intermediate and beginners. There was no criterion for selecting subject as they consist of male and female in different ages.

The instrument used in this study was questionnaire which delivered by google form. It is used in this study because online questionnaire considered the easiest and fastest way to collect data from the sample. The questionnaire includes 15 questions which the expected answers can illustrate the students' opinions toward SMALL.

The analysis showed by description about students' answer from the questionnaire, in order to show their perceptions about SMALL even had a positive attitude or negative attitude. Miles \& Huberman (Miles \& Huberman, 1994) steps to analyze data used in this study there are 3 steps, first data reducing by focusing data which related to students' perspective and using SMALL in Arabic learning into questionnaire, second display data by text description, and third conclusion drawing which appear in the last of displaying data.

\section{FINDINGS \& DISCUSSION}

The discussion is about the students' perception toward using social media in Arabic learning process which delivered on tables of percentage, and will be described in order to know what are their perceptions toward social media and what kind of social media that they usually used for their Arabic learning activity. The results of this research are:

Table 1. I have social media account, as Facebook, Instagram, What Apps etc.

\begin{tabular}{ccc}
\hline & Result & Percentage \\
\hline Yes, I have & 32 & 100 \\
I do not have & 0 & 0 \\
I am not sure & 0 & 0 \\
\hline
\end{tabular}

From table 1 above, seems that 100 percent of respondents have social media and they use it in their daily life.

Table 2. I believe social media can be used in Arabic learning

\begin{tabular}{ccc} 
& Result & Percentage \\
\hline Agree & 28 & 87.5 \\
\hline
\end{tabular}

Please cite this article as Risna Rianti Sari \& Albar Adetary Hasibuan. (2019). Students' Perception toward Social Media Assisted Language Learning (SMALL) for Arabic Learning. Izdihār : Journal of Arabic Language Teaching, Linguistics, and Literature, 2(2), 101-114. DOI: 


$\begin{array}{llc}\text { Disagree } & 0 & 0 \\ \text { Not sure } & 4 & 12.5\end{array}$

Table 2 Above shown $87.5 \%$ respondents agree that social media can be used in Arabic learning, while $12.5 \%$ not sure that social media can be used to learn Arabic.

Table 3. I use social media for enhancing my Arabic language skills

\begin{tabular}{ccc}
\hline & Result & Percentage \\
\hline Agree & 28 & 87.5 \\
\hline Disagree & 0 & 0 \\
\hline Not sure & 4 & 12.5 \\
\hline
\end{tabular}

Table 3 shows that $87.5 \%$ respondents used this social media for enhancing their skill in Arabic, but $12.5 \%$ not sure that sosial media can enhance their Arabic skill.

Table 4. Social media can provide positive results for improving my Arabic language

\begin{tabular}{|ccc|}
\hline & Result & Percentage \\
\hline Agree & 28 & 87.5 \\
\hline Disagree & 0 & 0 \\
\hline Not sure & 4 & 12.5 \\
\hline
\end{tabular}

Table 4 shows that social media can provide positive results for $62.5 \%$ respondents, while $12.5 \%$ respondents not sure about it

Table 5. Social media has changed my perspective on learning Arabic

\begin{tabular}{|ccc|}
\hline & Result & Percentage \\
\hline Agree & 20 & 62.5 \\
\hline Disagree & 4 & 12.5 \\
\hline Not sure & 8 & 25 \\
\hline
\end{tabular}

Table 5 above $62.5 \%$ respondents agreed that social media has changed their perspective, they agreed that Arabic learning not only learned traditionally, but also can follow this globalization era. While $12.5 \%$ not agree that social media changed their perspective, and $25 \%$ not sure about it.

Table 6. Social media makes Arabic learning process became more fun and interesting

\begin{tabular}{ccc}
\hline & Result & Percentage \\
\hline Agree & 29 & 90.6 \\
Disagree & 0 & 0 \\
\hline
\end{tabular}




$\begin{array}{lll}\text { Not sure } & 3 & 9.4\end{array}$

Table 6 shows that $90.6 \%$ respondents agreed that social media made their process in Arabic learning became more fun and interisting, while only $9.4 \%$ not sure both Arabic learning or social interaction that make them fun.

Table 7. Social media (youtube, Facebook, WA group, Instagram) provides contents of Arabic learning

\begin{tabular}{|ccc|}
\hline & Result & Percentage \\
\hline Yes, provides & 25 & 78.1 \\
\hline Not provides & 5 & 15.6 \\
\hline Not sure & 2 & 6.3 \\
\hline
\end{tabular}

Table 7 shows that From table above, $78.1 \%$ said that social media provides contents of Arabic learning even contents for reading, listening, speaking. While $15.6 \%$ can not find the contents og Arabic in social media, and 6.3\% not sure that include contents of Arabic or not.

Table 8. Social media helps improve Arabic communication with lecturers and classmates

\begin{tabular}{|ccc|}
\hline & Result & Percentage \\
\hline Agree & 20 & 64.5 \\
\hline Disagree & 5 & 16.1 \\
\hline Not sure & 6 & 19.4 \\
\hline
\end{tabular}

Table 8 shows that $64.5 \%$ respondents used this social media for improving their communication in Arabic language with lectures and classmates. $16.1 \%$ disagreed that social media can help them in communication, while $19.4 \%$ not sure about it.

Table 9. Social media helps me become autonomy learner (self-taught learner)

\begin{tabular}{|ccc|}
\hline & Result & Percentage \\
\hline Agree & 23 & 71.8 \\
\hline Disagree & 2 & 6.3 \\
\hline Not sure & 7 & 21.9 \\
\hline
\end{tabular}

Table 9 shows that $71.8 \%$ respondents stated that social media make them became autonomy learner, $6.3 \%$ not agreed about it and 21.9 not sure, are the contents explain the Arabic well or they still need lecturers' explain. 
Table 10. Social media helps me get a lot of information about Arabic contents

\begin{tabular}{ccc}
\hline & Result & Percentage \\
\hline Agree & 28 & 87.5 \\
\hline Disagree & 4 & 12.5 \\
\hline Not sure & 0 & 0 \\
\hline
\end{tabular}

Table 10 shows that $87.5 \%$ respondents got a lot of information about Arabic contents from social media, and $12.5 \%$ disagreed and got from the other resources.

Table 11. Social media makes me interact well with my lecturers and classmates

\begin{tabular}{|ccc|}
\hline & Result & Percentage \\
\hline Agree & 20 & 62.5 \\
\hline Disagree & 4 & 12.5 \\
\hline Not sure & 8 & 25 \\
\hline
\end{tabular}

Table 11 shows that $62.5 \%$ respondents stated social media can be used for interacting with lectures and classmate better than face to face, while $12.5 \%$ not agreed about that, and $25 \%$ not sure that they can take the benefit of social media for interaction.

Table 12. Social media has negative impact on my concentration in learning Arabic

\begin{tabular}{|ccc|}
\hline & Result & Percentage \\
\hline Agree & 13 & 40.6 \\
\hline Disagree & 13 & 40.6 \\
\hline Not sure & 6 & 18.8 \\
\hline
\end{tabular}

Table 12 shows that $40.6 \%$ agreed that social media disturbed their concentration and $40.6 \%$ the contrary of it while $18.8 \%$ not sure.

Table 13. I not find the benefit in learning Arabic by social media

\begin{tabular}{|ccc|}
\hline & Result & Percentage \\
\hline Agree & 3 & 9.4 \\
\hline Disagree & 25 & 78.1 \\
\hline Not sure & 4 & 12.5 \\
\hline
\end{tabular}

Table 13 shows that Only $9.4 \%$ respondents said that they can found the benefit of using social media in Arabic learning while $78.1 \%$ sure that it can be used, and $12.5 \%$ not sure about it. 
Table 14. Social media is more time consuming for me in social interaction than Arabic learning

\begin{tabular}{|l|l|l|}
\hline & Result & Percentage \\
\hline Agree & 17 & 53.1 \\
\hline Disagree & 8 & 25 \\
\hline Not sure & 7 & 21.9 \\
\hline
\end{tabular}

Table 14 shows that $53.1 \%$ respondents stated that social media was more time consuming in social interaction than learning Arabic, but $25 \%$ sure that they can used social media for learning more than they used it for private interaction, while $21.9 \%$ not sure which one is more between social interaction or Arabic learning.

Table 15. I prefer to use this social media for learning Arabic (you may choose more than one)

\begin{tabular}{|ccc|}
\hline & Result & Percentage \\
\hline Facebook & 7 & 21.9 \\
\hline Youtube & 22 & 68.8 \\
\hline Instagram & 15 & 46.9 \\
\hline Twitter & 3 & 9.4 \\
\hline Line & 3 & 9.4 \\
\hline Other & 4 & 12.5 \\
\hline
\end{tabular}

Table 15 shows that the table above shown that many students' used YouTube for their Arabic learning, it is about 22 students, and then Instagram about 15 students. Facebook, twitter, line and others used by students under 10 persons.

From the results of a survey of the opinions of students on learning Arabic using social media in the form of the table above, it can be summarized in the following points:

1. All students have social media

2. Social media can be used by students in learning Arabic, both in improving language skills, providing satisfying learning outcomes, making learning more fun and interesting, improving Arabic communication skills, making them interact better around learning. In essence, an average of 23 students found many advantages in using social media in learning Arabic.

3. Social media changes their perspective on learning Arabic. As digital natives, students can take advantage of technological developments in learning Arabic, so that what is originally traditional Arabic learning can be technology-based learning. 
4. Social media, aside from being used as a tool in the process of learning Arabic, also provides Arabic learning content that students can use to improve their Arabic language skills.

5. Social media can make students independent learners. This does not mean they do not need lecturers in the learning process, but rather make them more independent in seeking additional knowledge in addition to the knowledge they obtain during learning hours, to further add to their treasures about Arabic science.

6. But besides the benefits above, the use of social media in learning Arabic can also divert the concentration of students. Learning can be disrupted if in the process students are tempted to reply to messages, read status, read other information, so students spend a lot of time with their social media.

7. Social media that often used by students in learning Arabic are youtube and instagram. While other social media such as Facebook, Twitter, line and others were only used by less than 10 people from respondents surveyed.

This study about positive attitude toward using internet (mobile) was compatible with previous research such as (Yurdagül \& Öz, 2018), (Afshari, Ghavifekr, Siraj, \& Jing, 2013b) which the result showed students' positive attitude toward the internet that is very helpful and easy to use in learning a second language and also (Pirasteh, 2014) who concluded that it had an impact on increasing grammar point in teaching second language. Although many of students argue that SMALL was useful for learning, some of them also limit the use of mobile in learning because it can interfere with their concentration.

\section{CONCLUSIONS}

After receiving responses from students about their perspective on learning Arabic using social media, the results showed that they had a positive outlook on SMALL, on average 23 people from 32 respondents stated that social media had many benefits in learning Arabic. Those who have a negative view of social media as a tool for learning Arabic, argue that social media disrupts their concentration in the learning process and spends a lot of their time. The follow up study about using mobile in Arabic learning is needed for furthermore. 


\section{BIBILIOGRAPHY}

Afshari, M., Ghavifekr, S., Siraj, S., \& Jing, D. (2013a). Students' Attitudes towards Computer-assisted Language Learning. Procedia - Social and Behavioral Sciences, 103, 852-859. https://doi.org/10.1016/j.sbspro.2013.10.407

Afshari, M., Ghavifekr, S., Siraj, S., \& Jing, D. (2013b). Students' Attitudes towards Computer-assisted Language Learning. Procedia - Social and Behavioral Sciences, 103, 852-859. https://doi.org/10.1016/j.sbspro.2013.10.407

Ba「öz, T. (2016). Pre-service EFL Teachers: Attitudes towards Language Learning through Social Media. Procedia - Social and Behavioral Sciences, 232, 430-438. https://doi.org/10.1016/j.sbspro.2016.10.059

English Language Centre, the Hong Kong Polytechnic University, Hong Kong, China, \& Li, V. (2017). Social Media in English Language Teaching and Learning. International Journal of Learning and Teaching. https://doi.org/10.18178/ijlt.3.2.148-153

Eren, Ö. (2012). Students' Attitudes towards Using Social Networking in Foreign Language Classes: A Facebook Example. International Journal of Business and Social Science 3(20), 8.

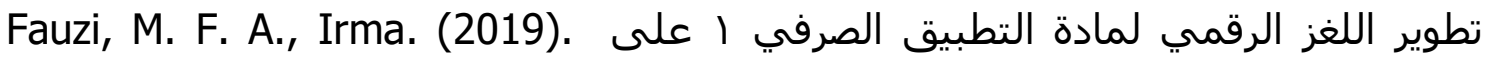
Buletin Al-Turas, 25(1), 129-139. doi: https://doi.org/10.15408/bat.v25i1.11506

Hasibuan, A. A. (2018). Computer Mediated Communication, the Way for Developing Students' Arabic Writing Ability. Computer Mediated Communication, 9.

Masqon, D. (2018). دور اللغة العربية في عصر العولمة وتطبيقها في تطوير العلوم. Jurnal Izdihàr: Journal of Arabic Language Teaching, Linguistics, and Literature, vol 1 no 2. https://doi.org/10.22219/izdihar. v 1i 1.6562

Miles, M. B., \& Huberman, A. M. (1994). Qualitative Data Analysis. London: Sage Publication.

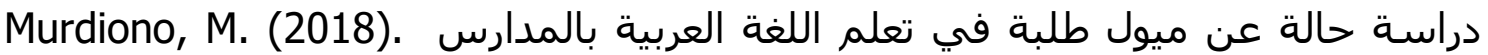

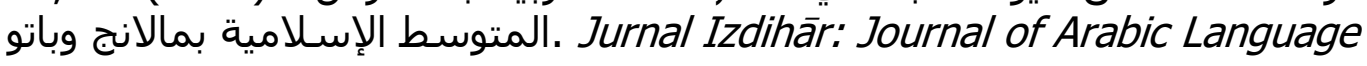
Teaching, Linguistics, and Literature, vol 2. DOI: https://doi.org/10.22219/izdihar.v1i2.7297

Nugroho, A. (2018). The Analysis of Hoax Spread in Social Media. 23. https://doi.org/10.9790/0837-2306065060 
Pirasteh, P. (2014). The Effectiveness of Computer-assisted Language Learning (CALL) on Learning Grammar by Iranian EFL Learners. Procedia - Social and Behavioral Sciences, 98, 1422-1427. https://doi.org/10.1016/j.sbspro.2014.03.561

Salih, A. A. A., \& Elsaid, D. A. S. (2018). Students Attitude Towards the Use of Social Media for Learning Purposes (Case Study: Al-Baha University, College of Sciences \& Arts- Biljurashi). Journal of LIterature, Language and Linguistics Vol 50, 7. ISSN 2422-8435

Watie, E. D. S. (2016). Komunikasi dan Media Sosial (Communications and Social Media). Jurnal The Messenger, 3(2), 69. https://doi.org/10.26623/themessenger.v3i2.270

Yurdagül, C., \& Öz, S. (2018). Attitude towards Mobile Learning in English Language Education. Education Sciences, 8(3), 142. https://doi.org/10.3390/educsci8030142 